\title{
Acousmatic and Acoustic Violence and Torture in the Estado Novo: The Notorious Revelations of the PIDE/DGS Trial in 1957
}

\author{
ANABELA DUARTE
}

\section{Introduction}

Following the recent exposure and debate on music as torture in the context of the so-called Global War on Terror and, consequently, on the role of music in penal institutions and police interrogation techniques under authoritarian regimes, this paper presents a series of data that point to the use of acousmatic and acoustic violence in Portuguese prisons during the Estado Novo (a dictatorial regime inaugurated by António de Oliveira Salazar) from 1933 to 1974. By acousmatic violence I mean the infliction of psychological pain on prisoners in detention through a panoply of pre-recorded sounds with no visible cause or source. In a situation of isolation and physical violence, the use of such sounds by dissociating sight and listening doubly exposes the individual to forced reduced listening (écoute reduite), which increases auditory hallucinations and perpetuates a lost sense of place and identity. By contrast, acoustical violence refers to the systematic use of aggressive noise, where sound sources are present and visible in what could be described as a situation of "direct listening."

The present work tries to explore and foster public awareness on some practices and microtechniques of such a repressive acoustic system, by highlighting forms of violence in prisons generally known as the "Segredo" and the unusual inquiry carried out by the Ministry of Justice into the activities of the police forces of the Portuguese fascist regime, ${ }^{3}$ which culminated in the trial of the PIDE/DGS (State Defence and International Police) in 1957. I examine the establishment and the end results of the systematic use of acousmatic and acoustic violence and torture upon political prisoners, which aimed at breaking their sense of self and personality, their character and ideological beliefs, and undermining their lawful defence. This instilled in the victims (as well as in their families and friends) an atmosphere of dread and terror that ultimately lead them to suicide or facilitated their assassination during detention. Personal testimonies of victims and perpetrators, acousmatic and acoustic evidence, and the display of electronic devices that operated in the "Segredo" in the 1950s bring to light the importance of sound technology and the international markets that promoted and purveyed their top products to the regime. In order to clarify the dynamics of this peculiar trial, I will start by overviewing the state of Portuguese justice and criminal law of the time (1926-1974, under the military dictatorship and Estado Novo) regarding the

\footnotetext{
${ }^{1}$ See Michel Chion, Guide to Sound Objects: Pierre Schaeffer and Musical Research, 11.

2 The "Segredo:" "A cubicle with no air inlet, no natural light, a sloping ceiling, and little space for humans, having only a wooden bunk for rest." See Arquivos PIDE/DGS, Serviços de Coordenação e Extinção da Pide, NT 704, PT5, 4.

${ }^{3}$ According to Manuel Braga da Cruz, Salazar denied any radical totalitarian and militarist connotations, defining his regime as a "constitutionalized dictatorship." See O Partido e o Estado no Salazarismo, 54-55, 77.
} 
treatment of political prisoners during interrogation and detention. ${ }^{4}$ However, this paper focuses on the postwar period, when the Plenary Court, as we shall see, reinforced repressive policies.

\section{The Judicial System}

In the beginning of the military dictatorship, courts were especially created to promote the legal condemnation of the so-called "political and social crimes" or "crimes against the State's security." Measures were taken to incriminate and hound anyone involved in activities-whether cultural, political, military, cooperative, unionist, or other - that were regarded by the authorities as an offense against the established order. ${ }^{5}$ However, the systematic repressive apparatus took shape only in 1933, with the rise to power of the new prime minister António Salazar, supported by a new Constitution that favored the authoritarian system and the growing power of the political police.

As a result, there were two separate political courts during this period; their profiles were directly connected to the years before and after World War II. The first of these courts dominated in the age of European fascism: the Special Military Court (Tribunal Militar Especial) gradually assisted in carrying out the orders of the political police, then called State Defense and Surveillance Police (PVDE). The second of these courts rose to power in 1945, after the defeat of the Nazi regime. Initially, that defeat compelled the regime to promise reforms in justice and "elections as free as in free England." Edmundo Pedro, who had been an inmate in Tarrafal Camp (Cape Verde) at the time, justifies the sudden, positive changes in the concentration camp:

Our living conditions changed dramatically for the better. Our connection to the living world was in part restored. Portuguese fascism was quickly trying to make its political conversion. It was trying to eliminate (and make us forget) the more conspicuous aspects that identified it with the dying regimes [Nazism] that had been its allies. ${ }^{7}$

As part of this fallacious political conversion to democracy in the face of postwar victories, the regime created the Plenary Court (Tribunal Plenário), which was in line with the policies of the newly created "International and State Defense Police" (PIDE). ${ }^{8}$

From 1945 onwards, appointed judges were replaced by those associated with the regime; moreover, the political police were given authority to institute legal proceedings, which meant that PIDE had the power to institute a case in a criminal court without further assistance from the lawful system: they were making the law themselves. Francisco Salgado Zenha and Abranches Ferrão, two Portuguese lawyers, claimed that from 1945 onwards the Portuguese penal system was a copy of the German system during the Third Reich, in which prosecution was controlled by the administration and the secret police. Consequently, the postwar "cosmetic" fascist regime did not change its modus operandi but only refined

\footnotetext{
${ }^{4}$ On the militarist character of the dictatorship, and the militarization of political life, see Fernando Rosas, ed., Tribunais Políticos: Tribunais Militares Especiais e Tribunais Plenários durante a Ditadura e o Estado Novo, 28-29.

${ }^{5}$ Rosas, Tribunais Políticos, 15.

${ }^{6}$ See Memórias: Um Combate pela Liberdade, vol. 1, 457.

${ }^{7}$ Ibid.

${ }^{8}$ Polícia Internacional e de Defesa do Estado, in Portuguese. Secret and special police corps existed before Salazar rose to power. The decree of March 17, 1926, created the Information Police, a secret and political police. Until then there were Special Police services only in Lisbon and Porto, both created in April 1927. In 1931, the International Portuguese Police (PIP) was created, and the Political and Social Defence Police (PDPS) followed on January 23, 1933. In 1933 the PIP merged with PDPS to form PVDE, coinciding with the systematic implementation of Special Military Courts. The PIDE was created in 1945 .
} 
its increasingly oppressive methods. ${ }^{9}$

Legally, the state prosecutor (Ministério Público) could not detain a suspect for more than fifty days, and even so a warrant for their arrest was required. The political police, however, could make arrests without a charge or a warrant and hold detainees in custody for as long as 180 days on the pretext of interrogation. Moreover, the implementation of the 1945 reforms allowed the political police to charge individuals indiscriminately and detain them for indefinite periods of time. It became common practice to release prisoners after six months in jail, and once they stepped outside the prison gates, to charge and arrest them again for another six months with no further investigation or formal charges. Some political prisoners were detained for four years without trial or any other chance of ending their imprisonment. At the trial itself, prisoners were still beaten in public or forced to remain silent, so as not to express their political convictions or denounce the torture and the physical abuse to which they were subjected. ${ }^{10}$ As many international observers on the political situation in Portugal have stated, trials and courts existed not to decide and pass sentence but to condemn political prisoners, meticulously following a repressive strategic agenda that was founded on intimidation.

In 1956, in the midst of fear and widespread political repression, a new law was implemented that reinforced the existing security measures concerning political prisoners; the periods of incarceration were extended one after another until they amounted in effect to a life sentence. Scholars compare this situation to the German act of 1935, in particular the Schutzhaft system, where the detention time had no limits and followed no legal prosecution. ${ }^{11}$ In fact, Portuguese intelligence kept in regular contact with the Gestapo and the OVRA (Organizzazione per la la Vigilanza e la Repressione dell'Antifascismo), Mussolini's political police. Captain Agostinho Lourenço da Conceição Pereira (1888-1964), one of the heads of Portuguese intelligence, both as PVDE and as PIDE, remained in power for twenty-three years; during World War II he collaborated with the Nazi regime, with which he traded in tungsten (wolfram) in his private capacity as businessman. ${ }^{12}$

From 1957 onwards a new period begins; special agents travel to elite training camps in the United States, such as Camp Peary, Virginia, also known as "The Farm," where they received instruction in methods and practices of interrogation from CIA experts. As we can see, there is a suggestive connivance between fascist regimes and democracies in the international environment of the 1950s, which makes it even more bizarre for the government to institute legal proceedings against PIDE in 1957, given the "totalitarian dérive" (as Evelyne Monteiro puts it) of the authoritarian regimes. ${ }^{13}$

\section{Repression and Counter-repression}

As we have seen, the regime's political police manipulated trials in the 1950s through preventive mechanisms, such as new reforms and new security measures. These mechanisms represented legal

\footnotetext{
9 Rosas, Tribunais Políticos, 2011, 16, 125.

${ }^{10}$ Ibid., 125.

${ }^{11}$ Evelyne Monteiro finds that the security measures imposed by plenary courts from 1956 onwards show the totalitarian and authoritarian shift of Salazar's regime, as they mirror, in legal terms, the German law of 1935 (Rosas, Tribunais Politicos, 138). In the same vein, Paulo Pinto de Albuquerque examines the similarities between the new security measures and the nationalsocialist Schutzhaft method (Ibid.).

12 Aljube/Exposição, “A Voz das Vítimas,” org. IHC/UNL, FMS, NAM (Lisboa, 2011).

${ }^{13}$ This totalitarian dérive took place with the connivance of the governments of the United States and some European countries, due in part to the concern about the Russian threat and the (apparent) success of Soviet communism. At the time, the Cold War predominated; the Berlin Wall, built in 1961, marks a deep rift between the East (Eastern bloc) and the West.
} 
micro-policies that were forged to ensure an increasing control of the country and the population. The most significant oppositionists—and by this I mean the Portuguese Communist Party-were sometimes described as a dangerous, illegitimate secret society "that aims at destroying and overthrowing the government by violent means":

The so-called Portuguese Communist Party is a secret, subversive association that seeks to destroy and change the form of government by violent means that are not allowed by the Portuguese Political Constitution; its members impose on themselves the obligation to conceal both the objectives of their meetings and the organization of their party from public authorities ... ${ }^{14}$

A new resistance movement emerged, however, and the customary framework of legal repression began to fissure, impacting the courts where it carried its maximum power. This created an extraordinary turning point in the situation. Letters of protest in favor of the prisoners who were harassed and tortured began to flood government institutions. In a joint effort, seventy-two Portuguese lawyers from Lisbon, Porto, and other cities prepared a comprehensive report on the repeated irregularities concerning the treatment of prisoners and the deaths that had occurred in state prisons. Joaquim Lemos de Oliveira, a barber and democrat from Fafe, aged 48, and Manuel da Silva Júnior, a worker and anti-fascist from Viana do Castelo, aged 69, for instance, had died inside a prison in Porto in 1957; officially, they had committed suicide. Álvaro Roçadas, a lawyer aged 62, declared in his statement on the recent deaths:

the declarant was the defence counsel for three of the defendants in a case against several young men in the plenary court ... he was made aware of the facts now mentioned in the legal challenge through his constituents. The fact was that on the corridors of the same court he had been told that a man had been found dead under unexplained conditions in the State Defense and International Police jail, and later he had also been told that in the same premises of the same police another death had occurred under the same conditions. ${ }^{15}$

Moreover, Luis Nogueira, a married man, aged 42, living in the municipality of Fafe, declared, "on one occasion an Agent whose name he cannot remember brought the man Oliveira in from the recreation area and called to the prison guard: 'Jailer, keep this scoundrel inside; he is dying on us but he never dies, does he, the motherfucker." 16 Given the citizens' growing indignation, the Ministry of Justice was forced to launch a broad and thorough inquiry into the methods and practices of the political police.

Some of the volumes of minutes from the 1957 proceedings and trial, including those covering the appointment of Judge Alexandre Soares Tomé to preside over this crucial inquiry, have been preserved in the Directorate-General of Archives (Torre do Tombo, Lisbon). From the statements of political prisoners-who were for the most part university students and young workers accused of being members of the Communist Party or the Democratic Unity Movement (MUD) ${ }^{17}$ - their defense counselors, and their families, we can understand with more accuracy how dramatic the situation in prison was and the role of music and sound in the overall picture of events. Statements from prison guards and intelligence agents are also available. Therefore, it is urgent to grasp the real conditions of internment and the acoustic and acousmatic mechanisms operating in detention facilities.

\footnotetext{
${ }^{14}$ Arquivos PIDE/DGS, Serviços de Coordenação e Extinção da Pide, NT 704, PT5, 195.

${ }^{15}$ Arquivos PIDE/DGS, Serviços de Coordenação e Extinção da Pide, NT 704, PT2, 101.

${ }^{16}$ Ibid., 115-116 and NT 704, PT4, 123-125.

${ }^{17}$ The antifascist Movimento de Unidade Democrática, founded on October 8, 1945, was outlawed in 1948 by Salazar under the pretext of its having strong links with the Communist party.
} 


\section{The Sound of the "Segredo"}

Political prisoners were locked in a very small space called the "Segredo," which consisted of a tiny cell with no natural light, no space to walk, and only provided with a wooden board where they may rest and sleep. The more fortunate, especially university students and individuals with an upper-middle-class background could enjoy a larger space if they paid the daily ten Escudos, but the cell was also damp and cold. The prisoner José Augusto Baptista Lopes e Seabra left an account of his experience on March 23, 1956: "For over a month he was locked in a wet cement cell without sufficient light or air. Then he was forced to pay the daily sum of 10 Escudos for he was threatened with the dungeons if he did not pay." However, the vast majority of prisoners were of humble origin, with no financial means to pay for the "accommodation"; others refused to pay to be in jail as a matter of principle. In addition, prisoners were tortured with physical violence and forced to stand up and remain motionless for many hours, in what is commonly known as the "statue torture" (estátua). They were forced to remain in that position for several days or even weeks and were deprived of sleep. Moreover, different voices shouted in their ears and repeatedly threatened them, overwhelming their sense of hearing and ultimately causing hyperacusis, amusia, and other hearing and psychological disorders. If anyone protested against these practices, the agents promptly replied that law prescribed such methods, as the prisoners were under a "continuous investigation." 18

In 1957 one of the prisoners, Humberto de Lima Morais, stated in his affidavit that after being subjected to the statue torture for several days, he had begun to hear a familiar voice at night. Listening more closely, he had been able to discern the words of a dialogue, in which one voice was clearly his mother's. She was saying: “I I am alone and I have no one else, please.' And the deep male voice of an agent, he thought, had replied, 'It is only for a day or two, madam." ${ }^{19}$ However, he could be inclined to admit that it may have been a hallucination, due to his weak physical state. The power of memory on our deepest perceptions and desires is paramount, so that each memory of a voice or other sound is always mediated, deferred and transformed, to a point that "we no longer know what we heard and what we think we'd heard. ${ }^{20}$ Nevertheless, based on similar cases and statements, such apparent hallucinations were actually the result of the use of manipulated sound materials, assembled to produce a state of emotional and psychological confusion through indirect listening, characteristic of acousmatic violence, with the aim of breaking and invading the prisoner's subjectivity and morale.

Something that contributed significantly to the use of sounds and music in interrogation rooms and in detention was the relationship between the Portuguese police and the CIA. In the Cold War period of the 1950s, the CIA installed Radio Free Europe ${ }^{21}$ in Glória do Ribatejo, Portugal, and on June 7, 1956, officially formalized the relation by inviting the new PIDE's director, António Neves Graça, to visit CIA headquarters. ${ }^{22}$ Here are two brief examples from a top-secret document with ten articles and several sections and clauses, entitled "Proposed Agreement Between the Policia International e de Defesa do Estado (PIDE) and the Central Intelligence Agency (CIA)":

\footnotetext{
${ }^{18}$ See Arquivos PIDE/DGS, Serviços de Coordenação e Extinção da Pide, NT 704, PT4, 202.

${ }^{19}$ Ibid.

${ }^{20}$ See Daniella Cascella, 6.

${ }^{21}$ Radio Free Europe was founded in 1950. It was conceived by George F. Kennan (United States Department of State) and Frank G. Wisner (Office of Policy Coordination, later the United States Central Intelligence Agency) to utilize the talents of post-World War II Soviet and East European émigrés in support of American foreign policy. See: Radio Free Europe, Radio Liberty. http://www.rferl.org/info/history/133.html (Acessed 10.10.2014).

${ }^{22}$ See Irene Pimentel, História da Pide, 120 and Nuno Vasco, "Escuta Telefónica," in Vigiados e Perseguidos, 115-118.
} 
I. In order to obtain optimum results in the fight against Communism the two services - C.I.A and P.I.D.E - may coordinate efforts and activities when it is foreseen that this coordination can better defend the two countries against Communist activities. With this purpose in mind, the two Services will exchange information, be it simply clarifying, or be it indicative of specific and concrete activities of the Communist organization, and will undertake joint operations and activities....

V. In recognition of the fact that PIDE wishes to expand its service and that it desires CIA to train certain of its officers, CIA agrees:

A. To train selected officers specially designated by PIDE to combat the Communist organization in all Portuguese Territories, tailoring the training to the particular area of activity.

B. To train a team of PIDE officers in anti-Communist operations against the Party in Portugal. $^{23}$

In Washington, the next year, in 1957, a Portuguese police team received regular training from the CIA at Camp Peary, Virginia. These residencies for intensive training had the code name "Isolation," and adopted the KUBARK interrogation manual, completed in 1963, as required reference material. The manual has a whole section dedicated to interrogation practices and methods in situations of war and imprisonment, entitled "The Coercive Counterintelligence Interrogation of Resistant Sources." Induced health impairment, pain, deprivation of sensory stimuli such as sleep and regular meals, and the use of all kinds of sounds to break the resistance of prisoners became the sine qua non of interrogation methods. Thus, there is some evidence that by 1957 the regime agents were familiar with the use of music and sound as a weapon and as torture. ${ }^{24}$

We must bear in mind that during World War II, the United States created a military "unit of deception" called the Ghost Army, which used sonic and electromagnetic (radio) mechanisms of deception - that is to say, a true acoustic and electro-acoustic system that aimed at deceiving the enemy using sound as a weapon:

"Ghost Army" was the nickname given to a division of the U.S. Army, the Twenty-Third Special Troops, stationed in Europe during World War II. They consisted of artists deployed in the fabrication of camouflage and fake inflatable equipment, and sound and radio engineers using equipments pioneered at Bell Labs.

Music and sound effects were recorded on the latest wire recorder model, an ancestor of the magnetic tape recorder, and then played by powerful amplifiers and loudspeakers mounted on armored vehicles. The editing and assembling of sounds aiming to inflict casualties on the enemy can be seen as a kind of prototype for subsequent experiments with sound in interrogation rooms. ${ }^{25}$

From the 1960s on, and especially in the 1970s, the use of sounds and music in interrogation rooms and detention intensified both for political reasons and because of the growth of sound technology. At this time, two episodes are noteworthy, both related to acoustic and acousmatic violence. On April 21, 1965, for example, Maria da Conceição Matos was arrested for activities against the security of the state. She was stripped naked and beaten by male and female agents. By the third day of torture without sleeping she

${ }^{23}$ PIDE/DGS, SC CI (2), 6341/A, PT2, NT7431, “American Service for the Exchange of Information,” 8,10.

${ }^{24}$ For more information see Suzanne G. Cusick, "Music as Torture/Music as Weapon," and "You are in a place that is out of the world: Music in the detention camps of the Global War on terror.,"

${ }^{25}$ Steve Goodman, Sonic Warfare: Sound, Affect, and the Ecology of Fear, 41. 
began to have hallucinations_-spiders in the legs of a table, walls moving — and heard piercing screams of people being tortured. At the end of the episode an agent started shooting pictures and a young male agent hummed a typical Portuguese Catholic song in honor of the Virgin Mary, entitled "On the Thirteenth of May." The intention is clear: to humiliate and taunt the victim, taking advantage of the religious connotations of the song to mock her for being a communist and an atheist. ${ }^{26}$ In 1973 another prisoner, Pedro Baptista, suffered the statue torture for a week and heard sounds of protest songs, serenades, and fados outside the prison. At first he thought they were an action of solidarity because of his situation, but he later concluded that they were an assemblage of pre-recorded sounds. ${ }^{27}$ The situation is similar to that experienced by Humberto Morais in 1957, as we have seen. However, the use of specific genres such as fado or Portuguese serenades, with their slow movements and feelings of longing, for instance, appeals to the important role of music in building emotional and autobiographical memories, as "listening to music (even when we listen passively) activates many psychological functions (emotion, memory, attention, imagery and so on) located in a distributed, overlapping brain network." ${ }^{28}$ Thus, by activating this connection of music with memory and with our past through emotional feelings, through a "feeling of knowing" (the music, songs, rhythms) the prisoner relates it to events and episodes in his life, making music even more powerful as a tool or a weapon that breaks the prisoner's defenses, his inner being, by opening an emotional fissure between the feelings of hope and beauty of the music heard and the actual state of psychophysical torture.

\section{The Use and Misuse of Technology}

The regime archives deposited in the National Archive provide evidence of contacts established in 1958 with pioneering French electronic trading companies such as Compagnie Générale de Télégraphie Sans Fil (CSF), a purveyor of equipment to the Paris police headquarters and the French Ministry of Interior (Service de Transmissions, Bureau Technique). The archives include documents and images revealing audio and telephone systems installed in patrol cars as well as cameras for police control and surveillance (see figures 1 through 4). ${ }^{29}$ The film cameras are described in a letter dated 1959 from Compagnie Générale de Télégraphie Sans Fil to Monsieur Da Costa, an agent from the Portuguese intelligence staying at the Hotel Daunou, Paris:

Monsieur, Comme suite à votre demande, nous vous prions de bien vouloir trouver ci-joint une documentation sur notre Caméra portable type CP 102. Ce modele a succédé au Cp 101, dont vous avez vu un exemplaire monté sur une camionnette de la Préfecture de Police de PARIS. Ce montage a été effectué par les soins des services techniques de cette Administration mais les photographies jointes à la notice que nous vous adressons illustrent avec quelle facilité cet équipement se prête aux utilizations les plus diverses ...

(Sir. In response to your request, kindly find attached the documentation on our portable camera model CP 102. This model has replaced model CP 101, which you have seen mounted on a truck of the Préfecture de Police in Paris. Although the mounting was done by the good offices of our technical services, the photographs accompanying the brochure attached illustrate how such equipment is easily suitable for the most diverse uses . . . $)^{30}$

\footnotetext{
${ }^{26}$ Rosa Nery Nobre de Melo, Mulheres Portuguesas na Resistência, 257-263.

${ }^{27}$ Pimentel, $A$ História da PIDE, 385.

${ }^{28}$ Lutz Jancke, "Music, Memory and Emotion."

${ }^{29}$ All images of this essay are authorized for this particular publication and under copyright by the Portuguese National Archives of Torre do Tombo, in Lisbon.

${ }^{30}$ Arquivos PIDE/DGS, SC, NT 9129.
} 


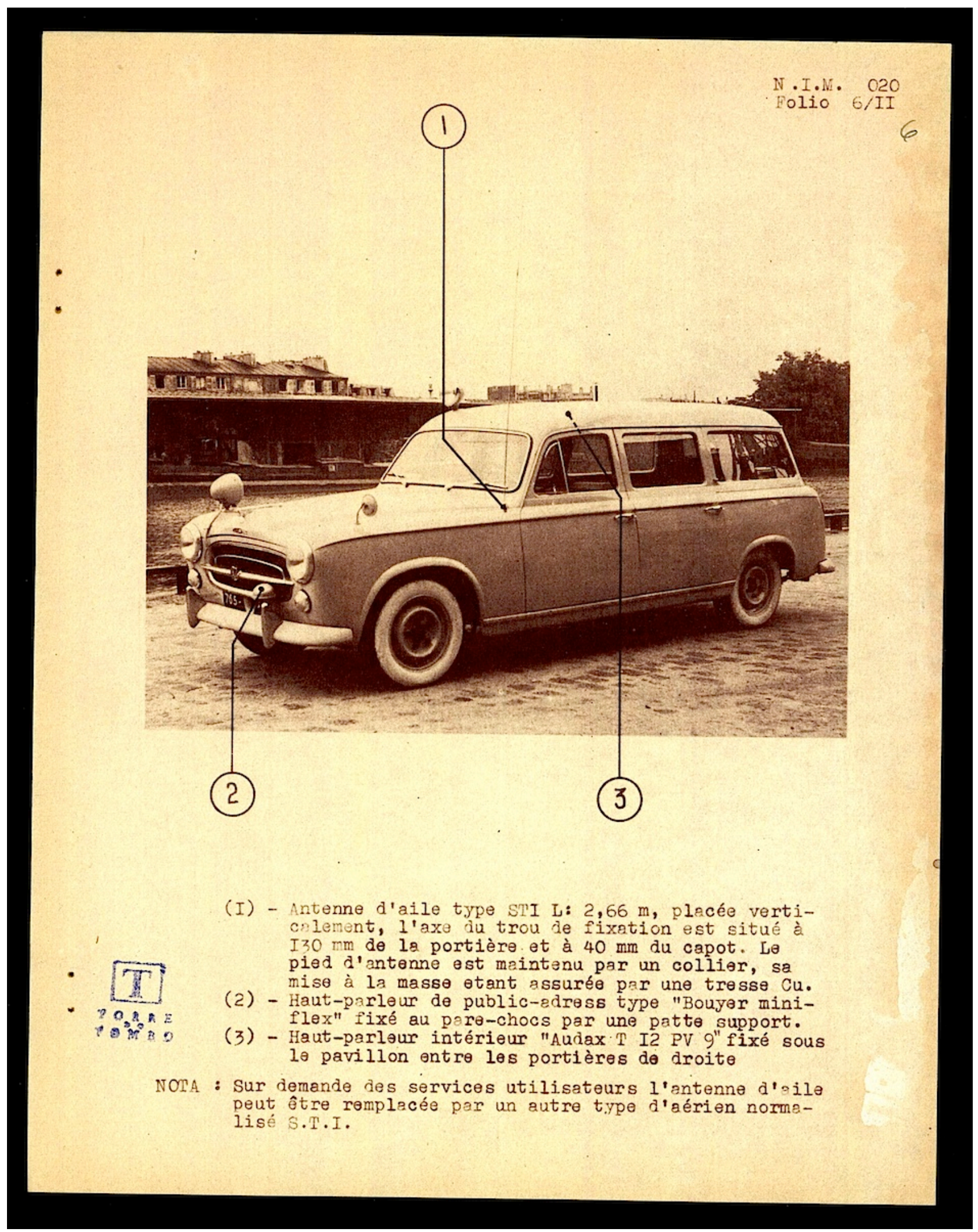

Figure 1: Patrol car (Peugeot) with audio system installed. ${ }^{31}$ 


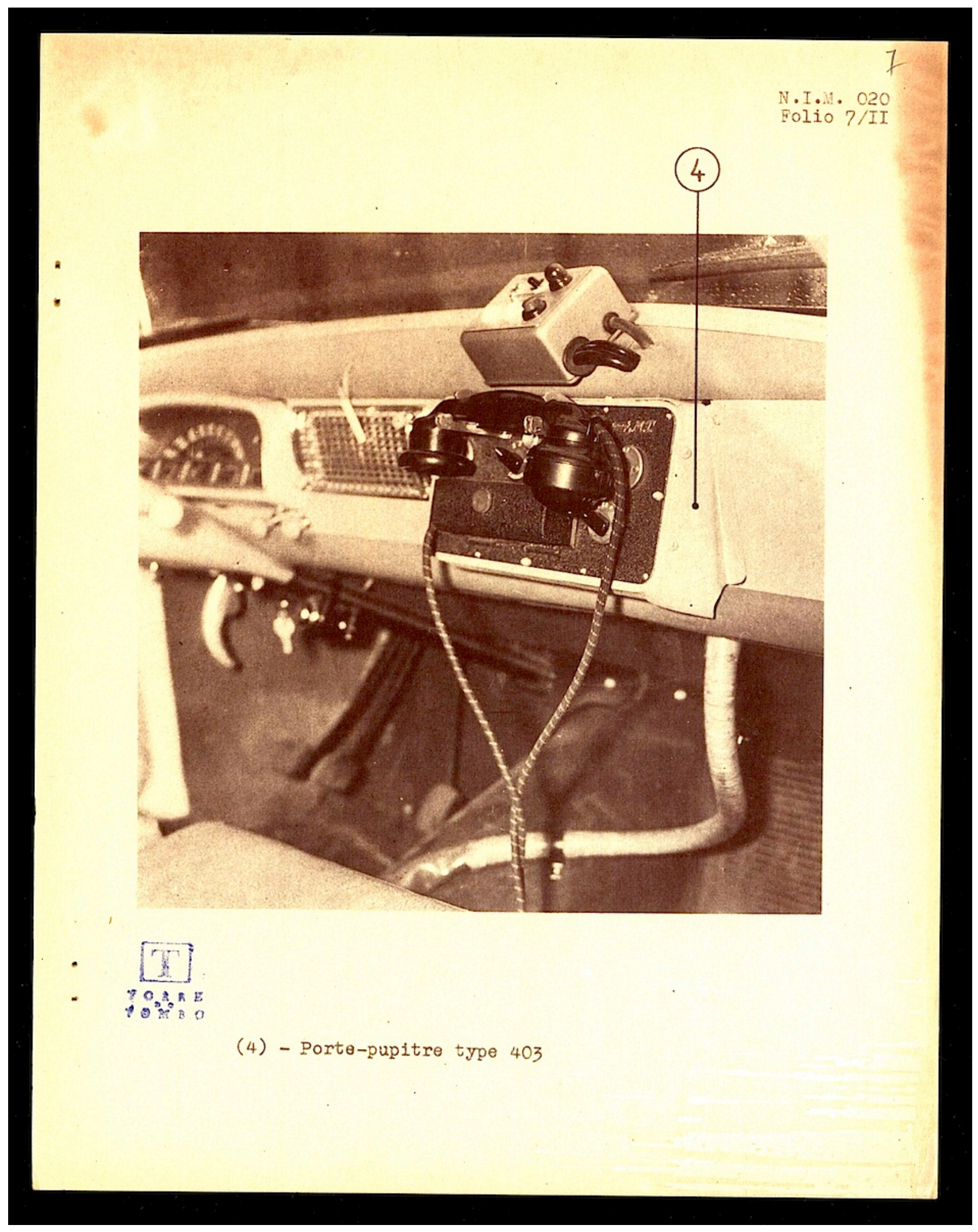

Figure 2: Patrol car (Peugeot) with telephone system installed. 


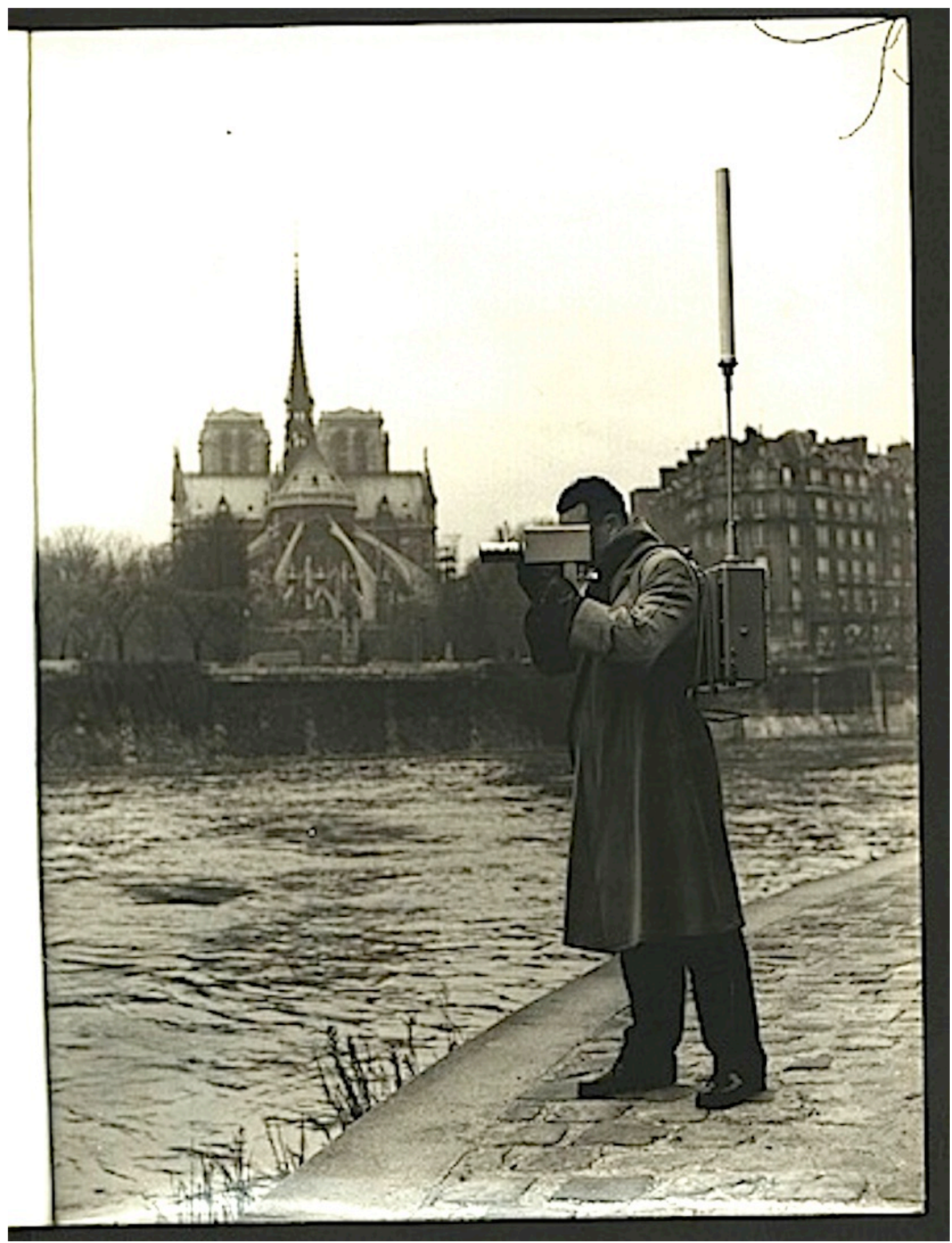

Figure 3: CP 102 Portable camera (1). ${ }^{32}$

${ }^{32}$ Fig. 3 and 4 in "Renault Domaine," PIDE/DGS, SC, NT 9129 


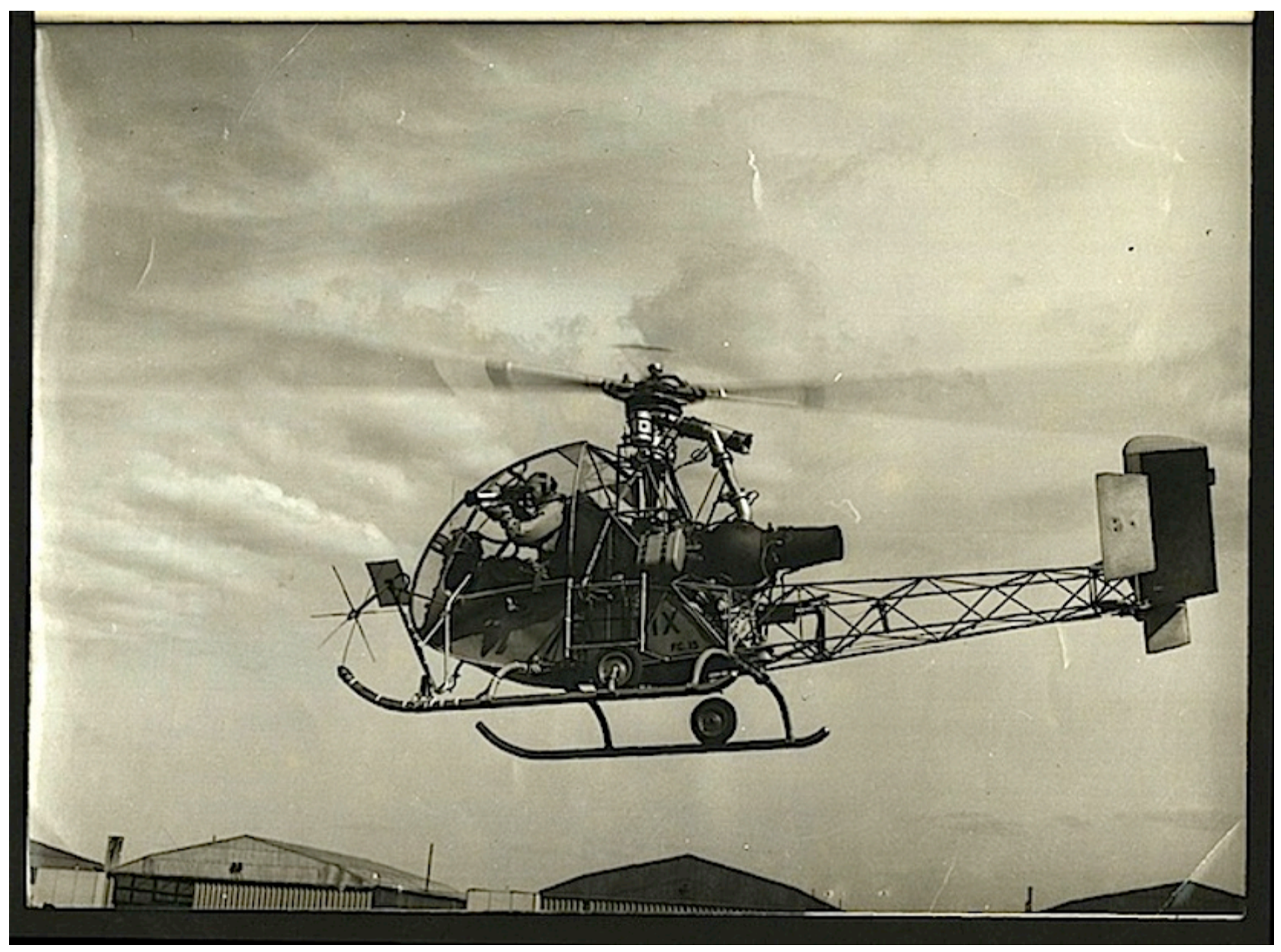

Figure 4: CP 102 Portable camera (2).

A few years later, documents dated 1965 record in detail the electronic audio system and equipment, together with nomenclature and prices, but no further description is given. Three types of equipment are listed, in order of importance and/or need: Équipement Indispensable de Base (essential basic equipment), Équipement de Reserve (reserve equipment), Équipement de Débordement (overflow equipment), followed by Table de lecture (reading table), Rebobineur (rewinder), Effaceur (eraser), amounting in total to 1.320.000 Escudos (about $€ 6.584,13$ ). ${ }^{33}$

Recorders, equalizers, and other editing and control equipment were mounted on the newest metal racks-just like the rack-mount systems that are indispensable in modern record studios today. This modern sound system, purchased from a French company and placed at the service of the police agency headed by Inspector Pereira de Carvalho, marks the beginning of a new and sophisticated era in Portuguese intelligence. Actually, all this equipment is extremely suited to the methods and techniques of interrogation and to the gathering of information used in the 1960s and 1970s (playback of recorded materials, phone tapping, hidden transmitters and recorders, amplifiers) due to its high level of sound capture and technological control; moreover, they offered vast camouflage possibilities, since the devices could be easily concealed inside what was ostensibly a mere piece of furniture with some drawer pulls. The methods and techniques of interrogation can be summarized as follows:

${ }^{33}$ Arquivos PIDE/DGS, SC, NT 9129. 
- Statue: standing position, sometimes facing the wall without touching it and with arms wide open;

- Sleep privation: the victim was not allowed to sleep for several days and/or weeks;

- Personal or family threats;

- General ill-treatment: for example, to burn the flesh with cigarette butts, kicks, force to defecate or urinate standing or, in the case of women, in front of the torturers with threats of rape;

- Speakers use: recorded voices, screams and crying that were placed in neighboring rooms and transmitted to the torture room to convince the prisoner that his friends or family were being tortured. $^{34}$

These tortures caused disorientation (loss of sense of place), disturbance of concentration, forgetfulness, and hallucinations, both visual and aural.

There is evidence that a new wiretapping system is also acquired at this time, and some of this equipment is to be part of it, as the list of materials suggests: "Ajouter les câbles d'installation téléphone et énergie, les réglettes, les contacteurs et les fers de fixation aux murs" (Add telephone and power installation cables, flanges, contactors and iron wall mounts). ${ }^{35}$ The photographs, classified as très secret, are quite informative about the intended purpose of the equipment, and from this we can infer the level of complicity and collaboration between high technology purveyors and the Portuguese dictatorial regime, among others. The extensive use of this equipment dates from the 1960s and 1970s, as noticed with Conceição Matos in 1965 and Pedro Baptista in 1973, but there are more examples. For instance, Carlos Coutinho, journalist and member of ARA (Armed Revolutionary Action), was arrested along with his wife and a daughter a few months old, in 1973. Under the statue torture he was forced to stay awake with strong slaps on the tabletop and violent shouting that "seemed to stick my head." 36 The agents shouted in his ears: "motherfucker, murderer! "Another boasted that he had raped his wife and others suggested they tortured his child. Time passed and he stopped being able to distinguish the days. He began to have hallucinations and tinnitus. The torture room, as he described it, was white with a yellow cement floor and a domed ceiling especially crafted for acoustical reflection. On the walls there were two false flowerpots with acoustic emitters inside. Later, he heard someone punching the walls, screams of a man being tortured, his wife's voice and his daughter's crying. ${ }^{37}$

However, the recording and editing of voices and sound effects for the purpose of torturing and tormenting prisoners was already in use in the mid-fifties, as we have seen with the testimony of Humberto de Morais Lima. The methods used at the time in Portuguese territory were substandard in terms of technology — that is to say, they were less sophisticated—but the declarations of the lawyers who counseled the prisoners and their families in the PIDE inquiry and trial provide significant examples that, surprisingly, these methods recurred before 1957. This is because many prisoners had been arrested several years prior to the trial in question, having their situation and declarations under detention being only revealed a posteriori in court to the public.

\footnotetext{
${ }^{34}$ Nuno Vasco, "Tortura," in Vigiados e Perseguidos, 103-104.

${ }^{35}$ Ibid. A brief paragraph of the exhibition "A Voz das Vítimas" ("The Voice of the Victims”) at the Aljube, Lisbon, 2011, corroborates this belief: "In the mid-1960s the political police acquired equipment that could record telephone calls. The main wiretapping, recording, and transcribing system was installed on the $4^{\text {th }}$ floor of the PIDE/DGS headquarters."

Aljube/Exposição, “A Voz das Vítimas” (Lisboa, 2011).

${ }^{36}$ Nuno Vasco, Vigiados e Perseguidos, 105.

${ }^{37}$ Joana Pereira Bastos, Os Últimos Presos do Estado Novo: Tortura e Desespero em Vésperas do 25 de Abril, 51; Vasco, Vigiados e Perseguidos, 104; Pimentel, A História da PIDE, 382.
} 


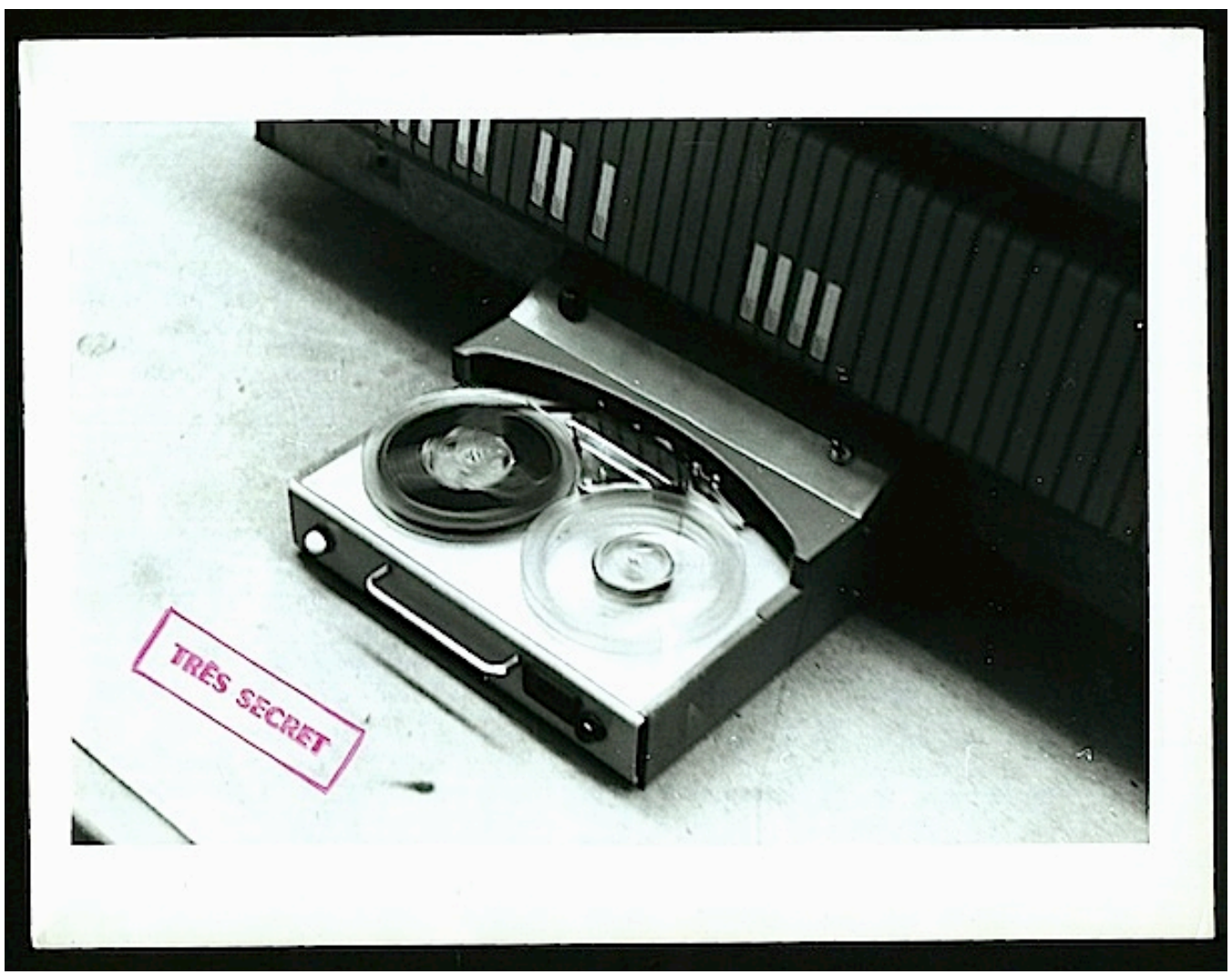

Figure 5: Rack-mount drawer (1) ${ }^{38}$

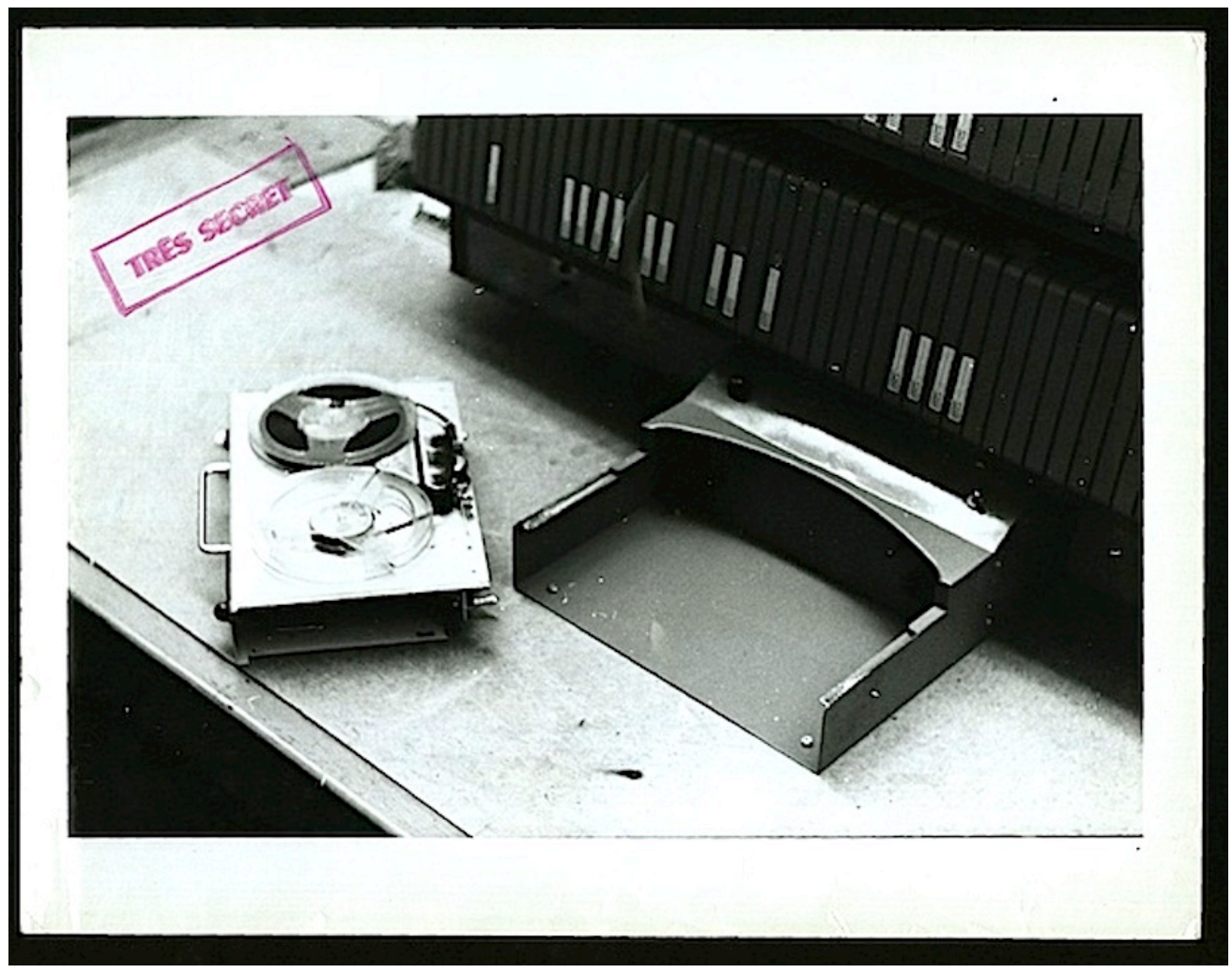

Figure 6: Rack-mount drawer (2)

${ }^{38}$ Fig. 5 through 8 in PIDE/DGS, SC, NT 9129. 


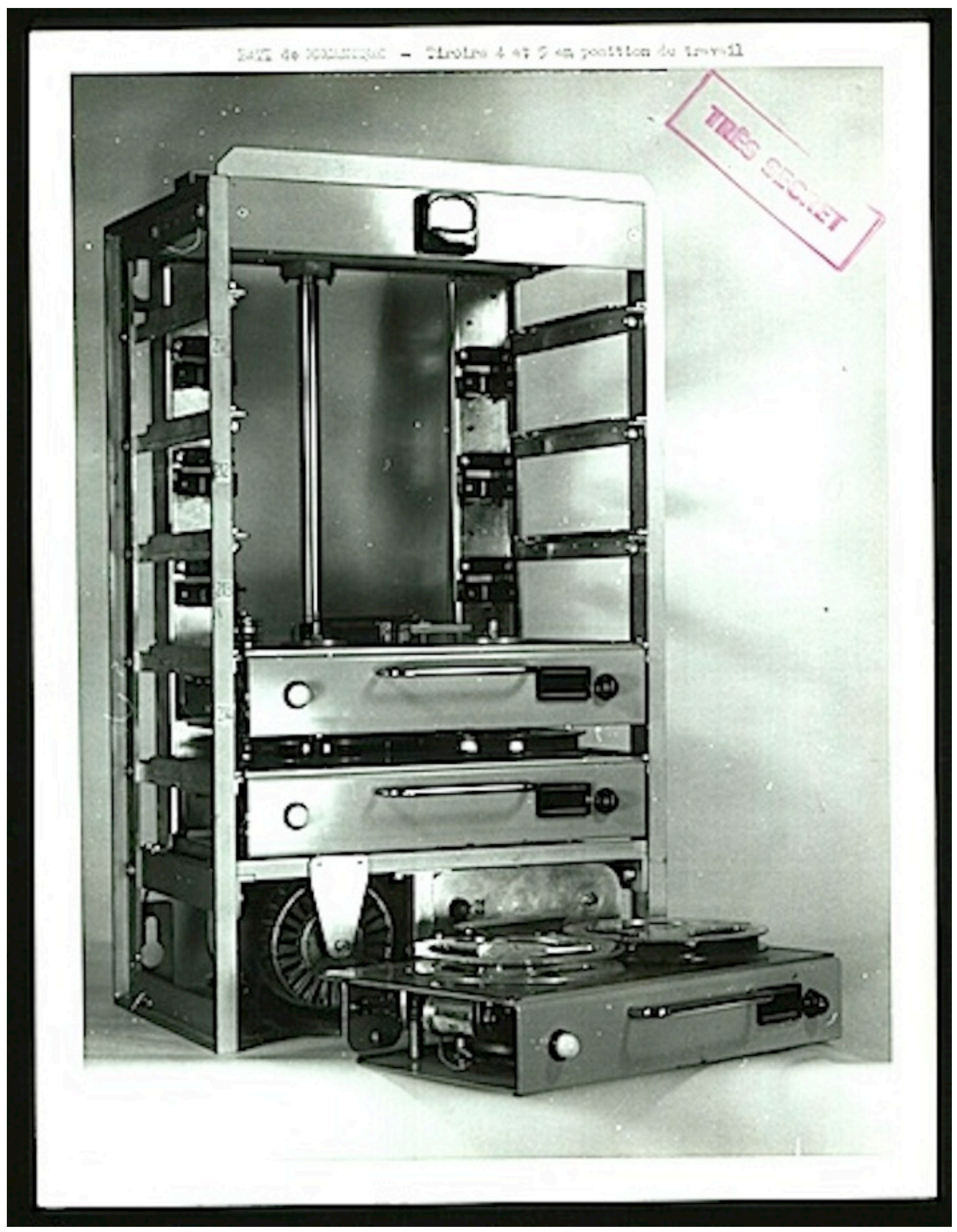

Figure 7: Rack-mount system with drawers 4 and 5 in working position 


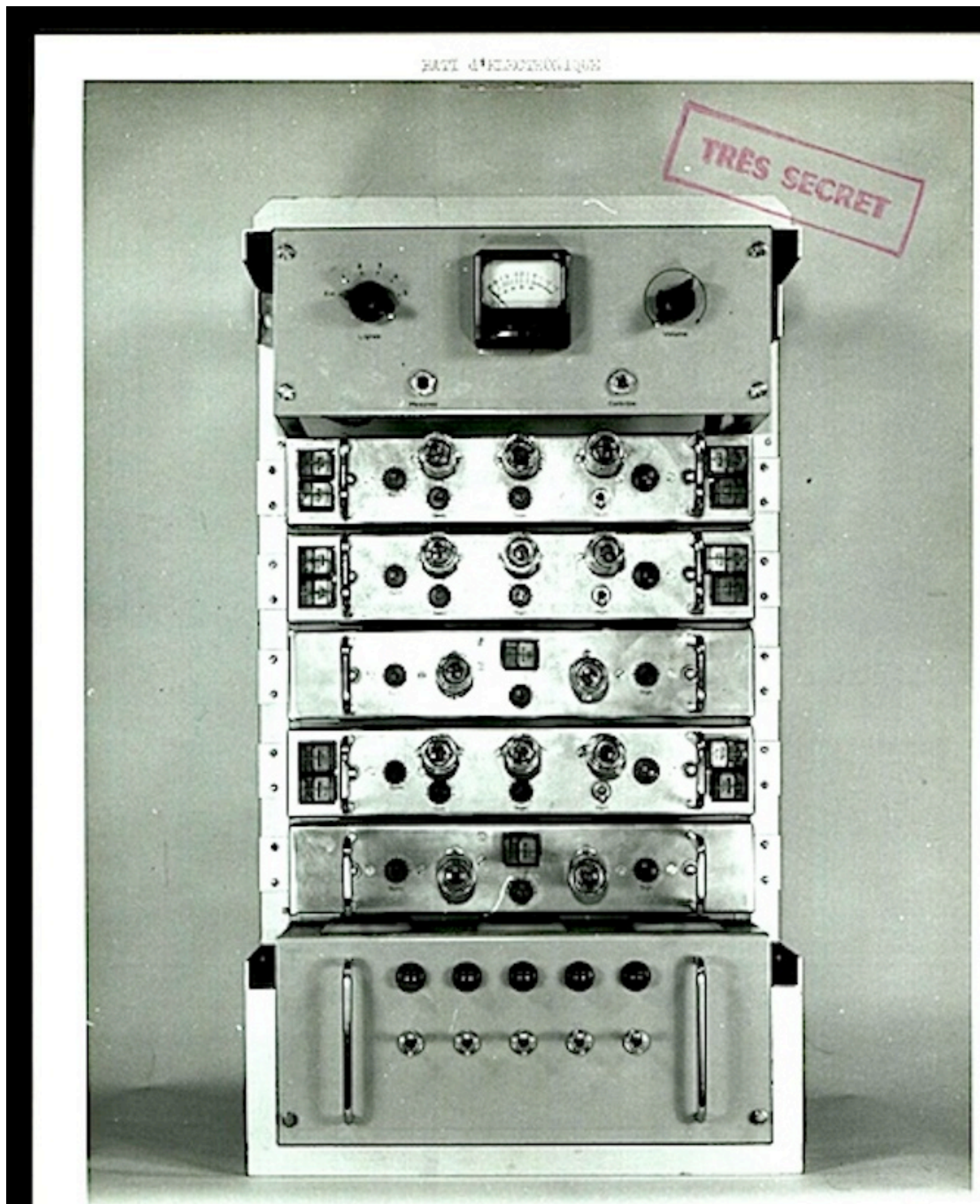

Figure 8: Electronic controls 
According to the lawyer Armando Bacelar, in 1955 the police did everything they could to frustrate the relationship between counsel and defendant, suppressing and systematically seizing his correspondence and protest drafts. They were planning to use those documents later against his clients, as this extract from his declaration indicates:

the Police restricted the relation between the declarant as defense counsel and his clients by suppressing and seizing correspondence, application drafts sent by mail, and by basing his client's interrogation sessions on that same correspondence. ${ }^{39}$

Further on, he declares that the interviews between counselors and defendants were suddenly relocated to the visitation area (Parlatório), ${ }^{40}$ where the conditions were inadequate, and states that he had heard rumors about two rooms having been altered to allow for the suspicious wiretapping:

At a certain point, and without any explanations, the counselors' visits to defendants were also transferred to the visitation area, in absolutely inadequate conditions . . . he knows that lately, as he heard from people who remained in the Police prison, those two cells at least were modified in order to make believe that they served other purposes than imprisonment. ${ }^{41}$

There was no writing table in the visitation area, and the defendants had to talk standing up, separated from their visitors by two grids, so that the agent could listen in from about one meter away. Sometimes the prisoners spoke "in cipher," i.e., a type of speech truncated by one or two words that hinted at the message but did not explicitly disclose it. ${ }^{42}$ Previously, the meetings were held in a small office. The doors were open, but the conversations could be heard directly by the agents, who stood at a fair distance. However, both the declarant and his client were placed next to a desk with the drawers closed, which led them to suspect that they were being overheard or their conversation was being recorded for later use by the police in court, as the lawyer declares in the following statement:

The declarant used to meet with his client in the visitation area in conditions that were not acceptable, as there was no writing table; the client had to be standing; both had to speak loudly, since they were more than one meter apart; and there was also an agent close by, who could hear everything that was said. Before being relocated to the visitation area, the interviews took place in a very small conference office on the top floor. The office door was always open, but the conversation could not be heard because the agents on guard in front of the door kept a fair distance. Nevertheless, the declarant and his client were placed near a desk with locked drawers. However, the declarant had already come upon an indirect way of listening in on conversations between counselors and their clients on two different occasions, once through headphones, and then through a recording device ... So, he is convinced that the reason for using those conference offices was to allow the Police to listen in on the conversation through those indirect means. ${ }^{43}$

Unquestionably, the use of "indirect means" is very suggestive of the presence of an "acousmatic

\footnotetext{
${ }^{39}$ Arquivos PIDE/DGS, Serviços de Coordenação e Extinção da Pide, NT 704, PT5, 104-05.

${ }^{40}$ The visitation area (Parlatório) is where the prisoners communicate with family members and/or authorized visitors. The prisoners are separated from the visitors by two grids stretching up to the ceiling, and forming a corridor where an agent walks up and down to monitor the visits. The prisoner is brought to the room on the ground floor, where the PIDE agent is already present. Later, the family is showed in. It all takes place in semi-darkness with continual interruptions from the PIDE agent at the slightest suspicion of an equivocal topic in the conversation. Wikipedia, s.v. "Cadeia do Aljube," last modified February 3, 2014, http://pt.wikipedia.org/wiki/Cadeia_do_Aljube.

${ }^{41}$ PIDE/DGS, Serviços de Coordenação e Extinção da Pide, NT 704, PT5, 105.

42 "Conversations 'in cipher,' that is, a truncated conversation, a normal conversation that is truncated now and again by a word that, by itself, signifies the idea the person wishes to communicate." Ibid., 103.

${ }^{43}$ Ibid., 106.
} 
experience," a new "listening in" on voice and speech that captures intensities and meaning not for creative purposes but for gathering useful information. Likewise, the use of electronic devices (recorders, headphones, microphones) was then, if not a common practice, surely a well known one among police agents in 1955. Either in conference offices or in prison rooms that were altered for that effect, which constitute a sort of "prepared" spaces for interrogations practices, this equipment served the purpose of gathering intelligence, and was also, as we have seen earlier, a form of acousmatic violence. In the case of conferences between attorney and client, the police intended to interfere in their relations and to illegally gather details and defense strategies. This information was to be used and manipulated later in plenary court, as Bacelar also describes:

an answer given by the police to the court, and included in this case, in which considerations are made by the police that reveal how they misuse their powers in order to gather information on the defense plans and details; and how they use that information to argue in a court of law; and even draw inferences from what was said that are damaging to the accused. ${ }^{44}$

\section{Inside-Out Resistance}

In addition to electronic sound devices for gathering information and torturing political prisoners, there were sets of micro-techniques that were also used to inflict psychological and physical damage in the context of the prisoners' detention and interrogation. The sleep torture, associated with the statue torture, as we have seen, requires the activation of sound mechanisms to keep the prisoner awake. Producing a number of aggressive noises becomes a real system of physical violence. It is seemingly innocuous, due to the "tools" that are used, but it is terribly effective in practice as, for example, rattling a handful of coins on a table top, scraping a plastic-glazed window with a pair of nail clippers, opening or closing a drawer with a bang, yelling, shouting, playing recorded threats and provocations, manipulating the silence (and the heating) of the room. Carlos Coutinho, a former prisoner in Caxias already mentioned, noticed sounds of coins spinning and hands thumping on the tables of the interrogation room when the sleep torture was inflicted. ${ }^{45}$

On the other hand, the prisoners developed musical and sonic resistance techniques in order to survive the long days, months, and even years spent in captivity. Inside the cramped "curros" of the Aljube prison, for example, the detainees sung, whistled, made sound signals and noises, and hammered with their fists as a means of communicating with each other or just to pass the time. ${ }^{46}$ They often used song and sound as forms of resistance. Edmundo Pedro recounts his time in the Aljube jail in 1934:

In spite of trying to sing the revolutionary songs that fed our militant enthusiasm in a moderate tone of voice, we were often ordered by the guards to desist under penalty of punishment. But the orders did not alter our determination. We merely lowered the tone for the moment."

Similarly, in regular prisons the inmates sometimes sang together in the exercise yard as a form of protest and resistance, challenging the very standards of behavior required and the surveillance agents, as we can see from this passage:

\footnotetext{
${ }^{44}$ Ibid., 105-06.

${ }^{45}$ Interview by Anabela Duarte, July 5, 2011.

${ }^{46}$ Curro, literally "the stall," is a hole of about one by two meters.

${ }^{47}$ Edmundo Pedro, Memórias: Um Combate pela Liberdade, vol. 1, 219. See also Artur Pinto, “A Voz das Vítimas,” 2011.
} 
Once, when he was on surveillance duty in the exercise yard, at about 15 minutes to the end of recreation time, some prisoners began humming a song, first softly and then more loudly. The declarant told them that they could not do this, and if they persisted he would have to end the recreation time, as was determined by his superiors, namely by order of the deputy director.

They complied, but then they went on singing, giving the declarant a significant look. ${ }^{48}$

Inside the prison, music and sound were a form of resistance and survival for the political prisoners; for the regime, they were a form of torture, humiliation, and repression. Through wiretapping and recordings, the intelligence police gathered information, and manipulated the defense material and the statements from prisoners, suspects, and lawyers. The PIDE had judicial power, and used lawyers and judges-with or without their consent-to camouflage or conceal their criminal practices in court, turning them into bastions of the repressive machinery of the state.

However, it was the plenary court that summoned hundreds of lawyers, suspects and prisoners, more than three hundred witnesses, and the police agents themselves. In doing so, the court overtly and inadvertently showed the general public the uses and misuses of a criminal investigation carried out by the political police and their violent and repressive methods. So it was that the court became a vehicle for propaganda against the government itself, putting the regime in the dock. ${ }^{49}$ From now on, the regime was much more careful about sanctioning collective trials of such scale and with such large numbers of defendants, for that had counterproductive effects on the country's image, on both a national level and, more importantly, an international level.

\section{Bibliography}

Abranches-Ferrão, Fernando de, and Francisco Salgado Zenha. O Direito da Defesa e a Defesa do Direito. Lisboa: Autor, 1971.

Arquivos PIDE/DGS. Lisboa: Arquivo Nacional da Torre do Tombo.

—_. "A Colónia Penal do Tarrafal." Lisboa: Arquivo Nacional da Torre do Tombo.

- Serviços de Coordenação e Extinção da Pide. "Processo de inquérito a serviços da Policia Internacional e Defesa do Estado.” NT 704 and 705. Vols. 1-10. . Lisboa: Arquivo Nacional da Torre do Tombo.

- Guia de exposição: O Arquivo da PIDE/DGS na Torre do Tombo. Lisboa: Instituto dos Arquivos Nacionais, 1997.

Bastos, Joana Pereira. Os Últimos Presos do Estado Novo: Tortura e Desespero em Vésperas do 25 de Abril. Alfragide: Oficina do Livro, 2013.

Caldeira, Alfredo, and I. P. F. R. eds. Aljube: a voz das vítimas. Lisboa: Imprensa Nacional-Casa da Moeda, 2011.

Castanheira, José Pedro. “Tarrafal: Verdades e Mentiras do Campo de Trabalho de Chão Bom.” ExpressoRevista Actual, August 14 and 18, 2010.

Chion, Michel. "Guide to Sound Objects: Pierre Schaeffer and Musical Research.” Binary Heap. 23 Aug. 2014 http://reaktorplayer.wordpress.com/2014/08/23/michel-chions-guide-to-sound-objects-pierreschaeffer-and-musica.

\footnotetext{
${ }^{48}$ Arquivos PIDE/DGS, NT 705, PT6, 190.

${ }^{49}$ Rosas, Tribunais Políticos, 133.
} 
Cruz, Manuel Braga da. O Partido e o Estado no Salazarismo. Lisboa: Editorial Presença, 1988.

Cusick, Suzanne G. "Music as Torture/Music as Weapon.” Trans - Revista Transcultural de Música, no. 10 (2006). http://www.redalyc.org/articulo.oa?id=82201011.

. "You are in a place that is out of the world': Music in the Detention Camps of the Global War on Terror." Journal of the Society for American Music 2, no. 1 (2008): 1-26.

Exposição “A Voz das Vítimas.” Antiga Cadeia do Aljube. Org. CML, FMS, 14 Abril-31 Dez. 2011

Gil, José. Salazar: a retórica da invisibilidade. Translated by Maria de Fátima Araújo. Lisboa: Relógio d'Água, 1995.

Goodman, Steve. Sonic Warfare: Sound, Affect, and the Ecology of Fear: Technologies of Lived Abstraction. Cambridge, MA: MIT Press, 2010.

Jancke, Lutz. "Music, Memory and Emotion.” Journal of Biology 7, no. 21 (2008). http://jbiol.com/7/6/21.

Madeira, João, ed. Vítimas de Salazar. Estado Novo e Violência Política. Lisboa: A Esfera dos Livros, 2007.

Melo, Rosa Nery Nobre de. Mulheres Portuguesas na Resistência. Lisboa: Seara Nova, 1975.

Pedro, Edmundo. Memórias: Um Combate pela Liberdade. Vols. 1 and 2. Lisboa: Âncora, 2007 and 2011.

Pimentel, Irene F. A História da PIDE. Lisboa: Círculo de Leitores, 2007.

Pinto Artur. "A Voz das Vítimas.” Lisboa: Sound Station, 2011.

Rosas, Fernando, ed. Tribunais políticos: Tribunais Militares Especiais e Tribunais Plenários durante a Ditadura e o Estado Novo. Lisboa: Círculo de Leitores, 2009.

Vasco, Nuno. Vigiados e Perseguidos: Documentos Secretos da PIDE/DGS. Lisboa: Livraria Bertrand, 1977. 


\begin{abstract}
Following the recent exposure and debate on music as torture in the context of the so-called Global War on Terror and, consequently, on the role of music in penal institutions and police interrogation techniques under authoritarian regimes, this paper presents evidence of acousmatic and acoustic violence used in Portuguese prisons during the "Estado Novo" under António Salazar's dictatorship. Focusing on the interrogation practices in prisons generally known as the "Segredo" and in the unusual inquiry carried out by the Ministry of Justice into the activities of the police forces of the Portuguese fascist regime, which culminated in the trial of the PIDE/DGS (State Defence and International Police) in 1957, this paper tries to explore and foster public awareness on some practices and micro-techniques of such a repressive acoustic system. I examine the establishment and end results of the systematic use of acousmatic and acoustic violence and torture upon political prisoners, which aimed at breaking their sense of self and personality, their character and ideological beliefs, and undermining their lawful defense. That instilled in the victims (as well as their family and friends) an atmosphere of dread and terror that ultimately led them to suicide or facilitated their assassination during detention. In the 1950s, personal testimonies of victims and perpetrators, acousmatic and acoustic evidence, and the display of electronic devices that operated in the "Segredo" bring to light the importance of sound technology, and of the international markets that promoted and purveyed their top products to the regime.
\end{abstract}

